\title{
SEMANGAT BUSHIDO DALAM NOVEL “MUSASHI" KARYA EIJI YOSHIKAWA (SEBUAH KAJIAN BUDAYA BERDASARKAN PENDEKATAN ANALISIS ISI)
}

\author{
Haryono \\ Fakultas Ilmu Sosial dan Pemerintahan - Universitas Jenderal Soedirman. \\ Kompleks FISIP Karangwangkal. \\ Jl DR. Suharso Purwokerto Jawa Tengah 53125. \\ Email: haryonoku@gmail.com
}

\begin{abstract}
The Spirit of Bushido in "Musashi" novel by Eiji Yoshikawa. The present research deals with the Japanese cultural values that described in the novel "Musashi" written by Eiji Yoshikawa. The objective of the research was to identify the Japanese cultural values and give usefullnes in digging superior values that can be applied in everyday life. With a content analysis approach, the Japanese cultural values can be expressed in a comprehensive manner. The results of the research are identification of the Japanese cultural values and can be used as a reference for the development of Indonesian cultural values.
\end{abstract}

\begin{abstract}
Abstrak. Semangat Bushido Dalam Novel “Musashi” Karya Eiji Yoshikawa. Penelitian ini berkaitan dengan nilai-nilai budaya bangsa Jepang yang terkandung dalam novel "Musashi" karya Eiji Yoshikawa. Tujuan penelitian adalah mengidentifikasikan nilai-nilai yang terdapat dalam novel "Musashi" dan memberikan rmanfaat dalam menggali nilai-nilai unggul yang dapat diterapkan dalam kehidupan sehari-hari. Dengan pendekatan analisis isi nilai-nilai budaya bangsa Jepang yang terdapat dalam novel Musashi karya Eiji Yoshikawa dapat diungkapkan secara komprehensif. Hasil penelitian berupa identifikasi nilai-nilai yang terkandung dalam novel "Musashi" karya Eiji Yoshikawa dan dapat dijadikan acuan bagi pengembangan nilai-nilai budaya Indonesia.
\end{abstract}

Kata kunci: Bushido, Nilai budaya, Novel Musashi, Eiji Yoshikawa

Novel sebagai perwujudan keinginan pengarang dapat merupakan media yang tepat sebagai sarana untuk mengembangkan kebudayaan, kesenian dan juga pengertian pengembangan tata cara, mode, gaya hidup dan norma-norma (Mc Quail, 1989:3). Hal ini diperkuat oleh Gates (1979:19) yang mengatakan bahwa "The book assumes whatever form is most effective in recording preserving and disseminating information and knowledge".

Karya fiksi yang diantaranya berupa novel merupakan sebuah karya yang menawarkan berbagai permasalahan manusia dan kemanusiaan, hidup dan kehidupan dalam interaksinya dengan lingkungan dan sesamanya. Novel merupakan hasil dialog, kontemplasi dan reaksi pengarang terhadap lingkungan dan kehidupan, novel seringkali menawarkan 'model-model' kehidupan sebagaimana yang diidealkan oleh pengarang.

Program pendidikan bahasa Jepang, Fakultas Keguruan dan Ilmu Pendidikan pada Universitas Hamka memiliki mata kuliah nihonbungaku. mata kuliah ini diberikan kepada mahasiswa semester tujuh yang berisi pengenalan hasil kesusastraan jepang baik berupa puisi, prosa maupun drama. mereka dapat memilih salah satu karya sastra yang akan dijadikan pembahasan dalam diskusi mata kuliah Nihonbungaku. Salah satu kajian yang diberikan adalah pembahasan isi novel.

Novel memiliki sifat yang hanya mengandalkan kekuatan kata-kata sehingga imajinasi pembaca tidak dibatasi oleh ilustrasi. 
Oleh karena itu untuk menikmatinya pembaca harus mengikuti alur cerita secara berurutan. Daya tarik novel yang lain adalah ceritanya yang beragam sehingga pembaca dapat termotivasi untuk membacanya apalagi dibumbui dengan cerita yang sensasional. Melalui cerita dalam novel, pembaca secara tidak langsung dapat belajar, merasakan dan menghayati berbagai permasalahan kehidupan sehingga dengan membaca, pembaca akan dapat menemukan nilai-nilai sosial yang dapat menyempurnakan proses penemuan dirinya. Pada akhirnya sebuah novel dapat mendorong pembaca untuk ikut merenungkan masalah hidup dan kehidupan sehingga dapat memanusiakan manusia.

Jepang sebagai negara maju dalam segala hal memiliki nilai-nilai budaya yang khas. Masyarakat Jepang memiliki nilai-nilai yang diyakini dan dijadikan prinsip secara teguh untuk membangun bangsanya. Hal ini dibuktikan ketika dua buah kota di Jepang yaitu Hiroshima dan Nagasaki di bom atom oleh tentara sekutu pada Perang Dunia ke Dua. Selama kurang lebih lima tahun setelah dibom, Jepang telah dapat membangun negerinya dengan segala kemampuannya. Ukuran dan nilai-nilai budaya Jepang didasarkan atas sikap hormat kepada otoritas luar. Otoritas luar itu dapat berupa otoritas raja, orang-orang tua dan tradisi yang selalu dihormati. Hal-hal itulah yang menjami lancarnya fungsi masyarakat Jepang. Konsep-konsep yang penting untuk memahami nilai-nilai bangsa Jepang adalah semangar Bushido.

Semangat Bushido merupakan kode etik golongan samurai yang menginginkan tetap terjaganya nilai-nilai yang dipunyainya. Kode tersebut menekankan kehidupan yang keras. Seorang samurai dididik untuk hidup sederhana dengan makanan, pakaian dan tempat tinggal sekadarnya. Mereka tidak menginginkan harta benda dan selalu menjauhi omong kosong serta hal-hal yang tidak perlu. Nilai-nilai yang terkandung dalam semangat Bushido menurut Nitobe antara lain adalah nilai-nilai keadilan, keberanian, kebaikan hati, kesopanan, kesungguhan hati, kehormatan, kesetiaan dan pengendalian diri.

Banyak novel yang berbicara mengenai nilai-nilai yang terkandung dalam semangat Bushido, namun hanya ada beberapa novel yang secara khusus membicarakan mengenai semangat Bushido. Novel-novel itu antara lain
Musashi dan Taiko karya Eiji Yoshikawa, Kuil Kencana karya Mishima Yukio dan Rahasia Hati karya Natsume Soseki. Eiji Yoshikawa, Mishima Yukio dan Natsume Soseki merupakan sastrawan utama yang mampu menggambarkan semangat Bushido yang dimiliki oleh bangsa Jepang secara lugas, teliti dan relatif sempurna.

\section{Perilaku Manusia dalam Novel}

Perilaku manusia dalam suatu masyarakat dapat diketahui dari pandangan budaya yang tercermin bukan semata-mata dari tulisan-tulisan saja namun dapat diketahui dengan cara menggali karya-karya fiksi atau non ilmiah seperti buku sastra ataupun novel. Oleh karena itu seorang pengarang tidak dapat melepaskan pengaruh lingkungan dan sistem nilai yang selama ini dianut masyarakat pengarang tinggal. Perilaku manusia yang terwujud merupakan hasil perpaduan antara lingkungn alam dan lingkungan sosial. Lingkungan alam mempengaruhi manusia pada tingkat intelektual. Pada saat manusia berkembang dalam lingkungannya, manusia bersosialisasi dengan berbagai macam individu di sekitarnya. Dalam perkembangan selanjutnya manusia juga berinteraksi dengan budayanya.

Pengarang akan berperilaku atau mengungkapkan pikirannya dalam tulisannya sejalan dengan budaya yang telah berkembang di dalam dirinya. Dengan menggali novel yang memiliki nilai sastra tinggi secara tidak langsung kita dapat mengetahui kebudayaan suatu bangsa dalam setiap masyarakat baik yang sederhana maupun yang kompleks terdapat sejumlah nilai budaya yang satu dengan yang lainnya berkaitan sehingga membentuk suatu sistem. Sistem itu merupakan suatu pedoman dari konsepsi ideal dalam kehidupan yang memberi pendorong kuat terhadap arah kehidupan warga masyarakat.

Dengan didukung oleh geografinya, bangsa Jepang mampu menciptakan kebudayaan yang istimewa dan rakyatnya juga mampu memelihara adat istiadat serta watak yang telah memberi mereka rasa kepribadian nasional yang kuat. Kekuatan dan stabilitas yang berasal dari unsur-unsur kehidupan nasional ini serta watak bangsa Jepang tentu tidak terbentuk begitu saja dan dalam tempo yang singkat. Hal itu bisa dilihat dari sejarah terbentuknya watak dan kepribadian bangsa Jepang yang akan menurun ke generasi selanjutnya pada abad pertengahan. 
Permulaan munculnya semangat Bushido dapat dirunut dari masa keshogunan Tokugawa. Pada saat itu pegawai pemerintah dan anggota angkatan bersenjata adalah para samurai yang memegang semangat Bushido dengan teguh sehingga secara tidak langsung mempengaruhi individu-individu pada masyarakat Jepang. Bushido yang berarti jalan hidup seorang prajurit memiliki nilai-nilai budaya dan etika yang penting pada jaman Tokugawa. Hal itu disebabkan samurai terwujud atau diduga kuat melekat pada pusat nilai-nilai bangsa Jepang. Sebab lainnya adalah fakta bahwa semangat Bushido menjadi kode etik nasional pada jaman Tokugawa atau setidaknya sebagian besar dari bangsa Jepang. Dua sebab ini dipertegas oleh Nitobe (1996:23) yang mengatakan bahwa :

\begin{abstract}
"Bushido which had originally developed from the practical necessities of warrior, came to be popularized by Confucian moral ideas, not only as the morality of the warrior class but as the cornerstone of national morals."
\end{abstract}

Semangat Bushido mempunyai falsafah yang mengagungkan kesabaran, alam pikiran dan perasaan. Semangat Bushido memberikan tekanan pada segi mental spiritual di atas segi lahiriah dan material. Meskipun segi lahiriah dan material tidak diabaikan namun yang dianggap menentukan dalam mencapai hasil adalah aspek mental. Semangat Bushido menurut Nitobe (1996:14) memiliki beberapa nilai-nilai budaya yang penting yaitu nilai keadilan, nilai keberanian, nilai kebaikan hati, nilai kesopanan, nilai kesungguhan hati, nilai kehormatan, nilai kesetiaan dan nilai disiplin serta mawas diri. Semangat Bushido memberikan peran yang begitu besar dalam pemerintahan, maka semangat Bushido yang berarti jalan hidup seorang samurai sekaligus merupakan moralitas manusia Jepang dan telah menjadi landasan Moral nasional bangsa Jepang.

Semangat Bushido memiliki kaitan yang sangat erat dan saling mengisi dengan agama Budha Zen dan Neo-Confusianisme. Hal ini karena agama Budha Zen memberikan sumbangan pada semangat Bushido yaitu memberikan disiplin untuk mengembangkan watak, kepercayaan dan kendali batin bagi diri sendiri yang diperlukan untuk menghadapi kehidupan di dunia. Oleh karena itu pada akhirnya hubungan ini membentuk watak dan kepribadian bangsa Jepang.

\section{Kajian Analisis isi dalam Karya Sastra}

Teknik analisis isi digunakan untuk melukiskan isi komunikasi yang nyata secara obyektif, sistematik, kuantitatif dengan memperhatikan konteksnya. (Krippendorf, 1993:15)

Teknik analisis isi melihat satuan-satuan analisisnya dalam bentuk paragrap yang disesuaikan dengan konstruksi kategorinya. Satuan analisinya adalah penggambaran semangat Bushido yang meliputi pernyataanpernyataan nilai keadilan, nilai keberanian, nilai kebaikan hati, nilai kesopanan, nilai kesungguhan hati, nilai kehormatan, nilai kesetiaan dan nilai disiplin serta mawas diri. Pernyataan yang diambil tidak mempertimbangkan arti kiasan/konotatif namun pernyataan itu adalah mandiri dan makna yang terdapat di dalamnya adalah makna tersurat dari pernyataan itu. Dengan pendekatan teknik analisis isi, penelitian ini bertujuan memperoleh temuan semangat Bushido yang digambarkan pengarang dalam novel "Musashi" karya Eiji Yoshikawa.

\section{Fokus dan Sub Fokus Analisis Isi Novel "Musashi"}

Fokus perhatian dari analisis ini adalah mengetahui bagaimanakah gambaran semangat Bushido dalam novel "Musashi" karya Eiji Yoshikawa. Sedangkan sub-fokusnya adalah delapan nilai yang dikandung dalam novel Musashi adalah yaitu sebagai berikut:

a) Nilai keadilan adalah pernyataan yang mengandung sifat adil dan tegas dalam memutuskan suatu masalah.

b) Nilai keberanian adalah pernyataan yang mengandung sifat keberanian dan kebenaran terhadap segala hal yang mengancam/menghadapi bahaya dan kesulitan.

c) Nilai kebaikan hati adalah pernyataan yang mengandung sifat kebaikan hati, kemurahan hati, kasih saying, simpati dan rasa cinta yang dianggap baik menurut sistem norma dan pandangan umum yang berlaku. 
d) Nilai kesopanan adalah pernyataan yang mengandung sifat sopan santun, rasa hormat, dan kesederhanaan menurut adat yang baik.

e) Nilai kesungguhan hati adalah pernyataan yang mengandung sifat kesungguhan hati, jujur dan ketulusan hati yang sungguhsungguh dan benar serta cocok dengan keadaan yang sebenarnya.

f) Nilai kehormatan adalah pernyataan yang mengandung sifat kehormatan dan perbuatan yang menandakan atau menunjukkan rasa takzim/khidmat dan bangga.

g) Nilai kesetiaan adalah pernyataan yang mengandung sifat kesetiaan, pengabdian yang tulus dan berbakti, taat serta patuh kepada pemimpinnya.

h) Nilai disiplin dan mawas diri adalah pernyataan yang mengandung sifat waspada, disiplin diri atas kemajuan/tugas dengan membandingkan hasil serta sasaran secara teratur serta menyesuaikan usaha/kegiatan dengan hasil pengawasan.

\section{Ringkasan Cerita Novel Musashi}

Pada tahun 1600 terjadi pertempuran di padang Sekigahara yang berakhir dengan kemenangan pasukan Tokugawa. Dua orang prajurit muda bernama Shimmen Takezo dan Honiden Matahachi selamat dari perang. Mereka menyelamatkan diri dan mendapat perlindungan dari seorang janda muda bernama Oko yang memiliki anak gadis bernama Akemi. Pelarian Takezo diakhiri oleh penangkapannya oleh pendeta Zen bernama Takuan. Setelah tiga tahun ditahan, Takezo oleh takuan diberikan penghargaan karena ia mau menuruti segala kemauan Takuan. Penghargaan itu adalah nama baru bagi Takezo yaitu Miyamoto Musashi.

Selepas dari tahanan Musashi mengembara ke berbagai kota di Jepang diantaranya ke Nara, Ise, Iga. Musashi juga tak ketinggalan mengembara ke Kyoto untuk menantang pemain pedang terkenal yaitu Yoshioka Seijiro. Musashi akhirnya dapat menemui dan mengalahkan Yoshioka Seijiro. Setelah makin banyak lawan yang dihadapinya dan kemenangan-kemenangan gagah berani akhirnya Musashi memutuskan menetap di Shimosa.

Awal April 1612, Musashi mendapat tantangan dari Sasaki Ganryu. Ia adalah pemain pedang yang sangat berbakat dan disegani.
Mereka bersepakat untuk bertarung di pulau Tanashima. Akhirnya dengan teknik pedang yang sangat tinggi Sasaki Ganryu dapat dikalahkan oleh Musashi. Suatu perbedaan yang sangat menonjol diantara keduanya adalah keyakinan. Sasaki Ganryu meletakkan keyakinannya kepada kekuatan dan keterampilan memainkan pedang sementara Miyamoto Musashi meletakkan keyakinannya kepada semangat untuk mendapatkan pencerahan.

\section{Implikasi dalam Pengajaran Kajian Karya Sastra Jepang}

Karya ini dapat dibahas dalam pengajaran kajian karya sastra Jepang di Indonesia sebagai berikut:

Mahasiswa yang mengambil mata kuliah NIHONBUNGAKU diberikan sebuah karya sastra Jepang. Salah satunya dapat diambil dari novel berjudul Musashi karya Eiji Yoshikawa. Mahasiswa kemudian dikelompokkan menjadi delapan grup. Mereka mendapatkan tugas untuk mencari nilai-nilai semangat Bushido yang tercermin dalam novel Musashi. Setiap kelompok mendapatkan tugas untuk mencari satu nilai semangat Bushido. Mereka diminta untuk berdiskusi mengenai kriteria nilai-nilai yang bisa menjadi salah satu nilai semangat Bushido. Tetapi sebelum mereka berdiskusi, dosen memberikan penjelasan berkaitan dengan batas-batas kriteria yang menjadi nilai dari semangat Bushido dengan mengemukakan teori tentang analisis isi.

\section{PEMBAHASAN}

Hasil pembahasan dan diskusi tentang semangat Bushido dalam novel Musashi karya Eiji Yoshikawa adalah sebagai berikut :

\section{Nilai keadilan}

Masalah nilai keadilan yang terdapat dalam semangat Bushido adalah masalah yang membahas hubungan manusia dan sesamanya, serta hubungan manusia dengan alam lingkungannya. Bangsa Jepang memandang hubungan manusia dengan sesamanya secara horizontal yaitu hubungan yang memandang bahwa apabila tingkah laku seorang individu dalam kehidupan sehari-hari tidak sesuai dengan 
norma yang ada maka individu yang tingkatannya sejajar akan memberikan peringatan. Bangsa Jepang juga memandang hubungan vertikal secara erat bila dikaitkan dengan hubungan tuan dan hamba sahaya. Namun seiring dengan perkemangan jaman, bangsa Jepang juga memiliki definisi keadilan yang mendekati definisi individualisme yaitu hasil yang diperoleh merupakan usaha kerasnya sendiri sehingga orang lain tidak boleh menikmati hasilnya.

\section{Nilai Keberanian}

Masalah nilai keberanian dalam semangat Bushido mencerminkan masalah mengenai hakekat hidup manusia. Jiwa menurut bangsa Jepang adalah segala-galanya dan abadi. Mereka memandang bahwa materi memang perlu namun materi lebih rendah tingkatannya karena materi adalah pelengkap saja. Mereka berpandangan bahwa hidup itu buruk, namun manusia dituntut untuk mempunyai keberanian untuk berikhtiar agar hiduo itu menjadi lebih baik. Mereka melakukan usaha memperbaiki hidup dengan menjaga dan memelihara jiwa sehingga untuk bertingkah laku dalam kehidupan sehari-hari manusia dapat memandang dengan penuh keberanian. Nilai keberanian inilah yang memungkinkan Jepang dapat membangun kembali negaranya dengan penuh keyakinan dan memandang materi sebagai pelengkap untuk mencapai jiwa yang bahagia.

\section{Nilai Kebaikan Hati}

Masalah nilai kebaikan hati dalam semangat Bushido mencerminkan masalah mengenai sopan santun. Nilai kebaikan hati memiliki orientasi kepada hubungan yang saling ketergantungan dengan sesama manusia. Hal ini diperkuat oleh pandangan bahwa sesuatu yang telah didapat seseorang wajib dibalas tindakan yang sama atau tindakan yang baik kepada orang lain walaupun orang menerima kebaikan darinya lebih rendah atau lebih tinggi tingkatannya.

\section{Nilai Kesopanan}

Masalah nilai kesopanan dalam semangat Bushido mencerminkan masalah mengenai hakekat dari hubungan manusia dengan manusia. Konsep nilai kesopanan bangsa Jepang adalah aturan-aturan yang menjadi kebiasaan untuk mengatur individu dalam tata cara seperti hukum. Nilai kesopanan ini berkaitan dengan seseorang yang memiliki kewajiban untuk mengindahkan sopan santun dengan melaksanakan semua perilaku keikhlasan, kesederhanaan, tidak hidup di atas tempatnya yang sesuai, mengekang pengungkapan emosi pada kesempatan atau suasana yang tidak cocok.

\section{Nilai Kesungguhan Hati}

Masalah nilai kesungguhan hati dalam semangat Bushido mencerminkan masalah mengenai hakekat hubungan manusia dan sesamanya, hakekat hubungan manusia dengan lingkungannya. Hal ini ditandai pada saat pemimpin Meiji memulai Restorasi yang kemudian terkenal dengan nama Restorasi Meiji, rakyat Jepang secara mental sudah jauh lebih siap untuk membangun. Dengan memakai adat lama dan agama Shinto serta kepercayaan terhadap tokoh kaisar yang merupakan keturunan dewa, pemimpin Jepang berhasil memotivasi suasana membangun dengan penuh kesungguhan. Pepatah Jepang yang berbunyi "semakin tinggi tanggungan badan kita, semakin tinggi tekad dan semangat kita berada di atasnya". Hal itu mencerminkan semakin berat beban yang dipikul dalam menjalani kehidupan maka semakin sungguh-sungguh juga mereka meringankan beban itu.

\section{Nilai Kehormatan}

Masalah nilai kehormatan dalam semangat Bushido mencerminkan masalah hakekat hubungan manusia dengan sesamanya. Kehormatan bertalian erat dengan bertempur sampai mati. Dalam keadaan tanpa harap seseorang harus membunuh dirinya sendiri. Bagi orang Jepang adalah merupakan suatu aib bila kehormatan meraka telah tercemar sehingga mereka memutuskan untuk mencapai Keten-

traman dengan cara mati tanpa meninggalkan aib. Aib merupakan sifat yang tertanam dalam kesadaran orang Jepang. Orang Jepang memberi segala kehormatan kepada orang yang lebih tinggi pada tempat yang sesuai tanpa memperhatikan apakah mereka benar-benar orang yang dominan dalam kelompok. 


\section{Nilai Kesetiaan}

Masalah nilai kesetiaan dalam semangat Bushido mencerminkan masalah hakekat hubungan manusia dengan manusia serta hakekat hubungan manusia dengan lingkungan alam sekitarnya. Kesetiaan/kepatuhan kepada seseorang yang lebih tua sangat ketat sampai yang lebih tua itu memilih untuk mengundurkan diri secara sadar. Karena dalam agama Shinto telah tertanam nilai-nilai kesetiaan dalam kehidupan sehari-hari maka partisipasi sepenuh hati rakyat Jepang bukan menjadi masalah.

\section{Nilai Disiplin dan Mawas Diri}

Masalah nilai disiplin dan mawas diri dalam semangat Bushido mencerminkan hakekat hubungan hidup manusia dan hakekat hubungan manusia dengan manusia. Disiplin kuat apabila terdapat pengawasan yang keras dari atas. Dengan analisis serupa maka rasa disiplin karena kurangnya pendidikan dan kematangan untuk manusia yang berasal dari suatu kalangan yang kurang memperhatikan pendidikan biasanya menunjukkan sikap tidak disiplin.

\section{KESIMPULAN}

Dari seluruh analisis yang telah dilakukan maka simpulan tentang semangat Bushido dalam novel Musashi karya Eiji Yoshikawa menunjukkan bahwa:

1. Nilai keadilan merupakan sumber kekuatan untuk memecahkan sesuatu masalah dengan logis, nalar tanpa ragu-ragu sehingga hasil

\section{DAFTAR PUSTAKA}

Gates, Jean Key. 1979. Guide to the Use of Books and Library. USA: McGraw-Hill

Inazo, Nitobe. 1996. Bushido:The Soul of Japan. Tokyo: Tuttle Corp.

Koentjaraningrat. 1990. Kebudayaan Mentalitas dan Pembangunan. Jakarta: Gramedia. yang diperoleh merupakan sesuatu ketetapan yang adil;

2. Nilai kebenaran merupakan kegiatan melakukan sesuatu dengan benar sehingga jiwa yang merupakan sesuatu bagian dari manusia yang berfungsi sebagai penggerak raga harus dapat mengatur dan mengendalikan raganya;

3. Nilai kebaikan hati adalah sifat yang tertinggi dari semua sifat yang ada dalam setiap diri manusia;

4. Nilai kesopanan merupakan saudara kandung dari kebaikan hati oleh karena itu mudahnya orang Jepang terluka oleh kegagalan, penolakan dan penghinaan membuat mereka sangat cenderung untuk melukai dirinya sendiri daripada melukai orang lain;

5. Nilai kesungguhan hati merupakan awal dan akhir dari sesuatu di dunia ini, tanpa keikhlasan maka tidak aka nada sesuatupun di dunia ini;

6. Nilai kehormatan menempatkan kesadaran yang tinggi dari martabat dan harga diri seseorang serta merujuk pada nama baik seseorang dalam kehidupan di dunia;

7. Nilai kesetiaan adalah pengabdian tanpa batas seseorang kepada pemimpin dan negara;

8. Nilai disiplin merupakan kondisi yang ulet dalam menghadapi masalah dengan tahan tanpa adanya rasa keluh kesah dan pada akhirnya menuntut pada diri kita untuk tidak mengotori ketentraman dan kebahagiaan sehingga dapat mengendalikan nafsu yang ada dalam diri manusia.

Krippendorf, Klaus 1993. Analisis Isi:Pengantar Teori

dan Metodologi. Jakarta: Sinar Harapan

Mc Quail, Dennis. 1989. Komunikasi Massa. Jakarta, Erlangga.

Yoshikawa, Eiji. 1993. Musashi. Jakarta: Gramedia 